\title{
Structural Holes and Bad Ideas: Liverpool's Atlantic Trade Networks in the Early-Eighteenth Century ${ }^{1}$
}

Historians have been complicating their understandings of networks, and especially mercantile networks. Moving on from a rather positivistic approach based on family, religion and ethnicity, research has now started to stress the inherent problems inherent in networks. ${ }^{2}$ Furthermore, researchers have started to stress the problems in constructing and maintaining networks of whatever type. ${ }^{3}$ However, far less work has been conducted on the problems encountered in developing and under-developed networks, where key actors may be unduly influential because they have access to new and/or highly-prized information. Such key actors (often but not always, Mark Granovetter's 'weak ties') can help to bridge what Ronald Burt has called structural holes in networks; that is, 'the separation between non-redundant contacts' ${ }^{4}$ Actors that stand near structural holes are 'at a higher risk of having good ideas' through the ability to better synthesise the various, different, and new information to which they have access. ${ }^{5}$ Moreover, that information is likely to be seen as high value and credited because that information is considered rare. Therefore, actors bridging structural holes are often perceived as positive players within a network. ${ }^{6}$ However, the very fact that these bridging actors have information arbitrage to their advantage means that they are also in a great position to act against the interests of the principal(s), especially where there is a lack of good governance. ${ }^{7}$ These opportunities could be seen as 'bad ideas', the opposite of Burt's good ones. This situation could lead to bad decision making simply due to a lack of competency, through positive adverse selection, or even fraud. ${ }^{8}$

Either of these behaviours could be seen as a type of network failure, which Andrew Schrank and Josh Whitford define as "the failure of a more or less idealized set of relational-network institutions to sustain 'desirable' activities or impede 'undesirable activities'. ${ }^{9}$ They posit two types of network failure: absolute and relative - the latter of which is more relevant to the discussion here. ${ }^{10}$ They argue that relative failure occurs when networks fail due to a lack of competencies (involuted), or due to opportunism (contested). The first is due to ignorance and a failure to absorb enough information, and the latter occurs where there is sufficient competence, but safeguards against mistrust and opportunism are absent. The colloquial, if clear way they sum 
this up, is the difference between a partner 'screwing up' and 'screwing you'. ${ }^{11}$ However, this chapter will argue that both types of this relative network failure can occur within the same network, and at the same time. Furthermore, it will argue that this does not necessarily mean that the network has failed or is failing in a developmental or under-developed context.

Bridging actors are clearly not going to have perfect information in a developmental context. Therefore, it is quite possible that adverse selection may occur, but without intentional moral hazard (involuted failure). It is equally true that fraud could occur on a large scale (contested behaviour). At the same time, such bridging actors, or middlemen, play a key part in market integration, despite the 'significant difficulties' they face in a context of new and developing markets, both in terms of geography and commodities, and indeed changing and/or new institutional contexts. ${ }^{12}$ However, without a developed network to oversee or correct these behaviours, they could go undetected for a long period of time. It is also quite possible that a network would continue and be (relatively) profitable, even if both of these behaviours were present. The other actors (especially the principals) might not realise that the adventure could be even more profitable because they do not realise that such behaviours are present. Actors might also trust strong ties, or those with rare or valuable information, because they want to believe it, or perceive that they have no other options. ${ }^{13}$ As long as the venture was successful to a certain extent, positive affect could cause relational cohesion and moral obligation, leading to a sense of group. This would become more reinforced over time with frequent exchange, because attachments can arise simply from the 'idiosyncratic investment of learning to work together' that produces pleasure over and above the economic profit. ${ }^{14}$ We know that economic actions are hardly ever taken by a mythical 'rational economic man', but occur within 'ongoing systems of social relations'. ${ }^{15}$ Therefore, actors may not feel that the network is failing if they are making some profit and good feelings are being produced from the transaction(s). Moreover, in the long term, a developing network should improve the quality of information by diffusing competence, which infers that lacking in competence is simply part of the process. ${ }^{16} \mathrm{We}$ might say therefore, from a broader perspective, that in a developing international trading environment a network with involuted and contested behaviours was performing as well as it could, or could be expected to do.In order to investigate the problems with developing networks these 
ideas are applied to a case study of Liverpool's developing Atlantic trade in the earlyeighteenth century. Whilst Europeans had been trading (and conquering) in the Atlantic world for over two centuries, Liverpool was still a minor, if developing port. It therefore provides an excellent prism for examining the problems with developing or under-developed networks. The next section outlines the context and the trading network. The following analyses the behaviour of two bridging actors; one of whose behaviour can cause the network to be characterised as involuted (relative failure due to lack of competency), and the other to cause it to be termed as contested (failure due to opportunism). The conclusion argues that despite the presence of lack of competencies and opportunism, this network was not failing, but was simply at one point in a process of development. Bad ideas were present, but did not represent failure.

\section{The Providence}

This case study derives from a voyage of the brigantine Providence 1711-13 which produced a case in the equity jurisdiction of the Court of Exchequer in 1714-16. ${ }^{17}$ This side of the Exchequer was established in the sixteenth century and whilst not as important as Chancery, it assumed its doctrines, and the two developed side by side thereafter. Many cases also came to this court that would have been under the jurisdiction of the Court of Admiralty in the seventeenth century. ${ }^{18}$ People often used the equity side of the Exchequer when the payment of debts to the crown was involved, in this case, customs duties. ${ }^{19}$ The Providence was supposed to go from Liverpool, to Belfast, to New York, to one of the Leeward Islands (St Kitts, Antigua, Montserrat and Nevis), and then return to Liverpool. The voyage was therefore a sophisticated if peripatetic one, which seems to have been normal practice at this stage of the development of the Atlantic economy for the Dutch and the English. ${ }^{20}$ Liverpool was then still a relatively small port of around 6,500 persons, but was building on its coastal and Mediterranean trade (with ports such as Livorno) by joining in the expanding Atlantic commerce. ${ }^{21}$ Indeed, at the very same time of the Providence's voyage, Liverpool's pro-active merchants were constructing the port's, and indeed, the country's, first wet dock, which was opened in $1715 .^{22}$ This was built specifically to cope with Liverpool's increasing trade with the continental colonies and the West Indies which had begun by $1665 .{ }^{23}$ Belfast was also an important port in 
the Irish trade, a mainstay of the Liverpool trade at this time. ${ }^{24}$ New York, taken from the Dutch in 1664, was a major entrepôt port on the eastern Seaboard. ${ }^{25}$ The Leeward Islands, having become independent from Barbados in 1670 were starting to show their potential following years of laggard growth in the seventeenth century. ${ }^{26}$ This was also a period of war, with the War of Spanish Succession (1701-14) mainly in the European context, and Queen' Anne's War (1702-13) in the Americas. By 1711-12, the war was being fought mainly in Europe and was to some extent 'on hold' during the peace negotiations of those years, even if many of them were in secret. ${ }^{27}$ However, whilst the new Tory government in Britain was more concerned with reconstructing trade and the colonies, there were still plenty of privateers for the sailors to contend with. ${ }^{28}$ There were therefore a number of elements making the voyage of the Providence developmental as well as potentially dangerous. This was especially true in the commercial context of the Caribbean where no chartered or regulated companies had overall (supposed) control of the trade from England. ${ }^{29}$

The sole owner of the Providence was John Cunningham, a non-conformist, which meant that he could not serve on the town council. ${ }^{30}$ However, this did not stop many elite Anglican merchants of the period adventuring goods on his vessels and under his management. These included Richard Gildart and William Clayton, both of whom served on the town council at various points, like many Anglican merchants, who dominated the Council. ${ }^{31}$ The Providence sailed from Liverpool laden with coal and salt in addition to a wide variety of textiles such as hats, linens, woollens, nails and iron for sale in New York and the Leeward Islands, with a stop in Belfast. ${ }^{32}$ The Providence returned from the West Indies with sugar and molasses. ${ }^{33}$ The crew also purchased provisions in Belfast and flour, pork, beer and other supplies in New York for sale in the West Indies, but the precise details are not recorded. ${ }^{34}$ However, the voyage did not go as planned, and the resultant case in the Court of Exchequer provides us with wonderful evidence of the problems of developing and underdeveloped networks during this formative period of Liverpool's Atlantic trade.

The Providence sailed from Liverpool on the $9^{\text {th }}$ March 1711 and arrived in the Belfast Lough the next day. She was supposed to sail to New York on the $21^{\text {st }}$ March, but did not leave for that port until the $28^{\text {th }}$ March 1711 . The Providence arrived in New York on the $16^{\text {th }}$ May 1712 [the Julian calendar still being in operation], after a 
journey of five weeks. She sailed from thence on the $4^{\text {th }}$ August 1712 [forty-six days longer than planned]. ${ }^{35}$ It was rumoured on board that she was bound for Antigua, which was sighted on the $31^{\text {st }}$ August (as was Barbados), but instead they sailed to Nevis, where they arrived on the $1^{\text {st }}$ September 1712 . They eventually left the island on the $3^{\text {rd }}$ July 1713 [250 days longer than planned], arriving in Liverpool on $6^{\text {th }}$ August $1713 .^{36}$

Much of the evidence as part of the case in Exchequer relating to this long and extremely delayed voyage concerns the existence or otherwise of a charter party, and moreover, the dead freight and demurrage payments deriving from any such Charter Party if it existed. ${ }^{37}$ There is also a lot of evidence given about exactly what a charter party was and how they should be enacted. This is rather strange as charter parties had been in 'common usage' for centuries, and so it is likely that this evidence was given as part of an effort to try and find out whether a charter party did in fact exist for the Providence, and if so, who knew about it. ${ }^{38}$ Indeed, some leading merchants who were 'very well skilled and experienced' in such matters, were chosen to arbitrate the case. $^{39}$ The arbitrators were John Earle, William Pemberton, Edward Tarleton, William Webster, Lewis Jenkyns, Jonathon Livesay and Thomas Seddon. ${ }^{40}$ Although the outcome of the case is unknown, they assessed that a further ninety six hogsheads of sugar and eighty bags of cotton wool, each bag containing two hundred weight, could have been freighted over and above what was imported (and for which freighters would have had to contribute if there had been a charter party). As the freight for sugar from Nevis to Liverpool was $3 \mathrm{~s} 6 \mathrm{~d}$ per hundred weight, this only amounted to $£ 28,0,0$. Furthermore, demurrage was estimated at $£ 1590,0,0$, and portage at $£ 1575,0,0 .{ }^{41}$ The Liverpool arbiters decided that in satisfaction of all Cunningham's demands as well as for freight of goods on board, as for dead freight and 'all their Clayms' they should receive twelve hundred and sixty pounds. Therefore a lot of money was at stake. ${ }^{42}$ It is not surprising then that the case documentation is filled with technicalities regarding charter parties, dead freight and demurrage. However, the evidence given by the litigants in their attempts to apportion blame for the delays encountered on the voyage (i.e. who caused the demurrage charges) tell us a lot about the behaviour of the ship's captain Joseph Pearson, and the supercargo John Whiteside. Quite apart from the money at stake, the court case may have been a way of unearthing information about these two men, without accusing 
them directly, which may have been difficult in a close-knit socially-embedded trading network such as in Liverpool. The merchants may have been concerned about the financial outcome of the case, but finding out whether these men could truly be trusted may have been equally important to them.

Figure 1 outlines the network as constructed from the Exchequer records. The cluster on the top right is the dense network of Liverpool merchants exporting and importing on the Providence. The group on the bottom right are those giving evidence on the case, but not involved in the voyage. The network to the left of centre is the ship's crew (or at least those that gave evidence). From the far left of Figure 1 it is clear that the records show very little evidence of networks in New York and the Caribbean. This could be due to the nature of the sources, but the evidence within them suggests that there were in fact few developed networks on the Western side of the Atlantic, despite the fact that some of the adventurers had traded to the West Indies before. ${ }^{43}$ John Cunningham, the owner, is in the middle, but it is clear that Joseph Pearson the captain and John Whiteside the supercargo were extremely important bridging actors both geographically and within terms of the trading network in which there seems to have plenty of structural holes. They were therefore likely to be trusted and their information valued, but they also had opportunities for moral hazard and fraud. In fact, their respective behaviour could easily be characterised as lacking in competency (involuted) or fraudulent (contested) and therefore be termed as a case of relative failure within the network. As mentioned above, the embedded nature of the relations within this network may have made it impossible to accuse either of these men directly. This does not necessarily mean that the network failed however. By looking more closely at their reported actions and behaviour we can better analyse their role as bridging actors in this network. These records, whilst flawed and incomplete, tell us a lot about how and with what problems mercantile networks were developed in earlymodern Atlantic trade.

\section{Figure 1}




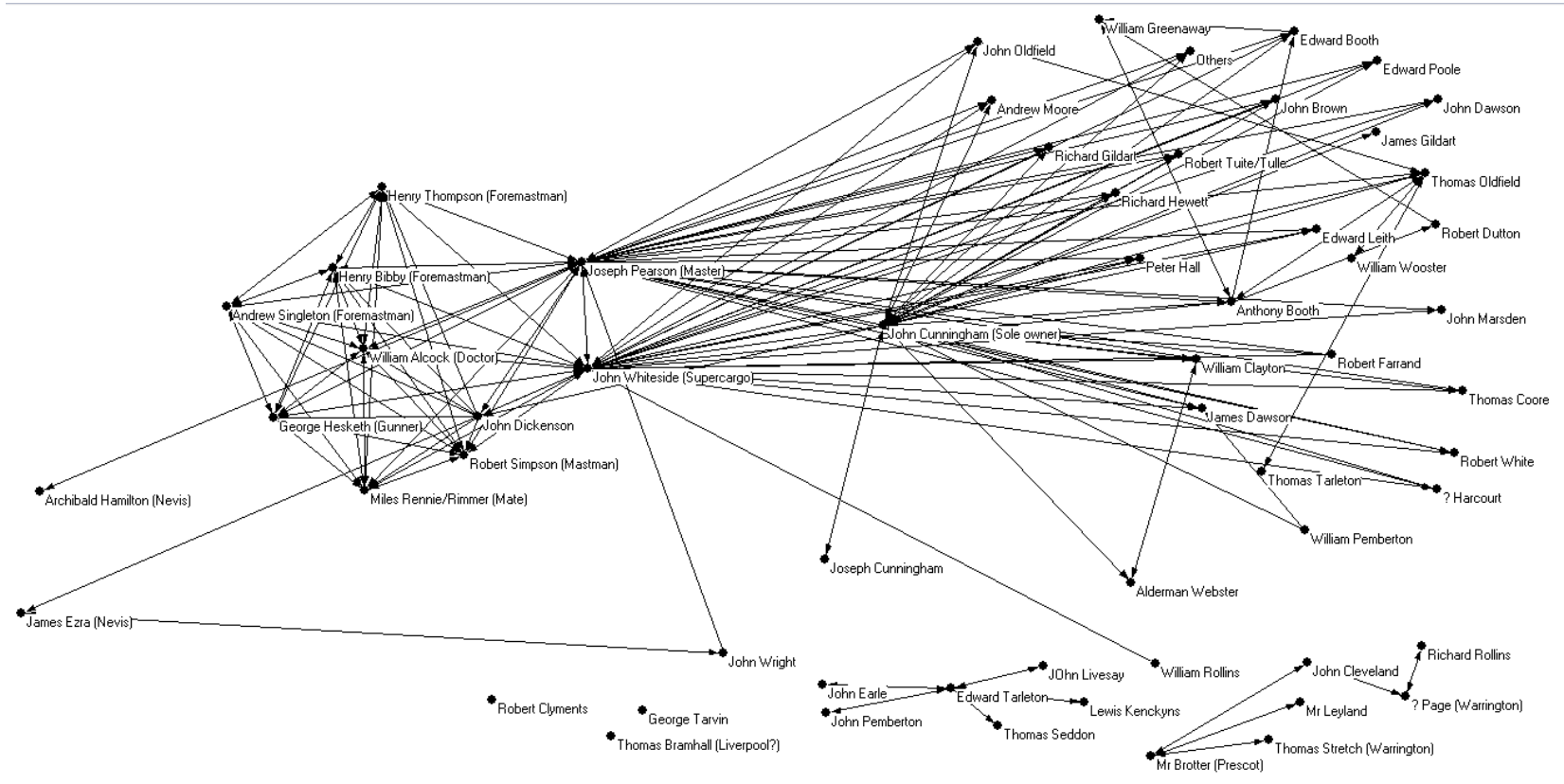

Source: Interrogatories, 16 November 1714, E134/1Geo1/Mich 37; Interrogatories, 8 April 1715, E134/1Geo1/East21; Decree, 1716.

\section{Joseph Pearson: Involuted Failure due to Incompetence?}

Joseph Pearson was the captain of the Providence. He was also a joint complainant with John Cunningham (the sole owner) in the original case in Exchequer, and therefore in opposition to the majority of the merchants involved in trading on the vessel (as shown in Figure 1 above). It would therefore appear that he was on the same side, or at least, continued to be trusted by Cunningham after the Providence's voyage. However, there are several aspects of his behaviour that others in the network thought worth commenting upon in answer to the pre-set questions posed them. $^{44}$

The first was regarding the delayed sailing from Belfast Lough by a week. Henry Bibby, the foremastman (who gave evidence for the defendants in the original case), said that the originally planned sailing date of $21^{\text {st }}$ of March had been good for sailing, that the ship had been ready, and therefore the delay was due to the "neglect and Omission' of Pearson. ${ }^{45}$ Other ships had sailed at this time without a problem he added. Bibby further commented that Pearson had said that he was waiting for a signal or ensign - but that he [Bibby] did not know the real reason for the delay. John Marsden was a merchant in 1715 but was the captain of the Tabitha and Prescilla, 
also in Belfast in March 1711. He confirmed that Pearson was due to sail from the Lough on the $21^{\text {st }}$ March in the company of the Tabitha and Prescilla, the Elizabeth and Ann and the Three Sisters, the latter two of Liverpool, for 'the greater safety' of all ships, as the first had guns to combat privateers. ${ }^{46}$ Pearson stayed behind though he could have sailed, but Marsden did not know why he chose to either. Only one person, Henry Thompson, another foremastman, gave an explanation as to why Pearson did not sail with the other vessels. He reported that by the mistake of a pilot the Providence was hindered and retarded in her passage, and therefore lost the company of the other ships. ${ }^{47}$ This was not confirmed by any of the other deponents however. ${ }^{48}$ It is difficult to say why Pearson delayed so long. It is unlikely that he was waiting for information from Liverpool - that was only a day's sailing away, and we have no further clues as to the signal for which he was purportedly awaiting.

Bibby, who appeared to have plenty to say about Pearson (perhaps because he had allegedly refused him permission to put some sugar on board at Nevis), thought that this late sailing had serious repercussions. ${ }^{49}$ When the Providence arrived in New York on the $16^{\text {th }}$ May 1712 they found that a London ship had come in two weeks before and 'lower' $d$ the Markett' [sic]. ${ }^{50}$ He believed that if the Providence had sailed for New York on the $21^{\text {st }}$ March they would have come to a better and higher market, and that 'the Adventurers or persons who were Concerned in freighting the Said Ship were considerable loosers[sic] by the Said Ship not Sailing from Belfast when ready as aforesaid'. ${ }^{51}$ Although trade was still rather peripatetic, a May arrival would have been late compared to other vessels arriving for the spring trade after the Hudson had melted. Therefore, it is worth noting that the vessel had left Liverpool quite late in the first place for a good spring arrival in New York.

A second matter mentioned by several deponents was the seizure of the Providence in New York by Customs Officers. This was due to some coals being taken on board by Pearson without the proper certification. Bibby said that the vessel lay under condemnation for one month during which time the coals and other goods were sold by the Customs Officers. However, Henry Thompson argued that the officers only pretended 'to have authority', and that the coals were only seized for four or five days, after which time the vessel was entirely discharged of her cargo. ${ }^{52}$ It is not clear whether any correct documentation was eventually produced, whether this omission 
was explained away, or whether there was an error on the part of the customs officials. Either way, it seems that Pearson's error was due to lack of experience, rather than being fraudulent.

The third matter of some confusion was the intended destination in the West Indies. Bibby, yet again ready to give evidence against Pearson, reported that the rumour was that the Providence was bound for Antigua, and that this was confirmed by the sailing course. ${ }^{53}$ Indeed, the vessel came in sight of St. John's harbour on the $31^{\text {st }}$ August 1712, but according to Bibby, Pearson ordered the sailors to make for Nevis, which was indeed where they made land. Bibby thought this hazardous due to privateers being in the area. Indeed the Leeward Islands were all attacked by the French in periods of war, and St Kitts and Nevis particularly so. ${ }^{54}$ Andrew Singleton, another foremastman on the Providence, also reported that Whiteside had wanted to go to Antigua but that Pearson said that he could not justify this to the owner unless Whiteside could confirm the vessel would be fully loaded there, which the supercargo could not. ${ }^{55}$ This is strange as of the Liverpool adventurers that had traded to the West Indies during 1709-10, Antigua was the most popular island, and only William Clayton had exported to Nevis that year. ${ }^{56}$ According to Bibby, the decision to go to Nevis was a bad one as when then they arrived at the island on the $1^{\text {st }}$ September 1712 sugars were very scarce. This was not surprising since the harvest would have begun in January and continued until May. ${ }^{57}$ There were also several other ships there, including some from New York, which had no doubt pushed up the price of sugar and made sales of the Liverpool and New York exports more difficult. Bibby continued that the ship's doctor, William Alcock, had been told that prices were better in Antigua, which he suggested confirmed the losses for the adventurers. ${ }^{58}$ This indecision over the destination in the Leeward Islands caused friction, but Pearson once again appears to have been acting in a trustworthy manner. ${ }^{59}$

As we shall see below, Whiteside was accused of not getting freight as he should have done for the return voyage to Liverpool, but according to Bibby (yet again) Pearson also discouraged some factors from putting freight on board. Apparently Pearson (who clearly thought there was a charter party) told Archibald Hamilton and several others not to put goods on board because the charter party meant that their goods would be seized on arrival in Liverpool on account of 'deadfreight and demurrage' 
[that is they would be seized until the extra costs were paid]. ${ }^{60}$ This is indeed what happened, but this behaviour is strange. Perhaps Pearson was trying to create a good reputation for the Liverpool merchants he represented by being so honest. Certainly it hurt them financially in the short term. Alternatively Pearson may have been building up his own good reputation for when he might become a merchant in his own right in the future.

A last aside that Bibby made against Pearson was to report that he went on the Jolly, man of war. His tone is accusatory, yet this was a time of war, and Pearson could simply have just been getting the latest information to protect the vessel and its crew. ${ }^{61}$ Given that the Leeward Islands lay near Martinique and Guadeloupe, the bases of French power in the eastern Caribbean, this was a very real danger at this time, Nevis having been attacked in $1706 .{ }^{62}$

\section{John Whiteside: Contested Failure due to Opportunism?}

In contrast to Joseph Pearson, the supercargo, John Whiteside, was one of the defendants in the original case. It would appear that he had had some falling out with John Cunningham the owner, but he was on the same 'side' of the case as the other merchants who were involved with the venture. However, his behaviour does seem far more suspect than that of Pearson.

Whilst Pearson had held up the Providence for a week or so in Belfast, Whiteside was accused of holding up its progress from New York for three weeks, in fact in all they stayed forty-six days longer than specified in the [alleged] charter party. Henry Thompson, the foremastman, gave evidence that on arrival in New York in May, the crew was busy following Whiteside's orders in delivering the cargo, including the coals that had been temporarily seized on arrival. Once the vessel was completely cleared, the crew then applied themselves to reloading the vessel according to Whiteside's orders, apparently as per their instructions in the charter party. ${ }^{63}$ Once this was done the Providence sailed into the North river and had the 'Jack and Antiant'[sic] flags flying as signals of readiness to sail from New York. ${ }^{64}$ However, Whiteside was not then on board, and it was only when he came on board three weeks later that the Providence and its crew finally set sail for the West Indies. Andrew 
Singleton, another foremastman, confirmed this delay adding that the 'ship continued waiting for the defendant [Whiteside] who as reported had not finished his business thereabout', though there was no comment as to what this business might have been. ${ }^{65}$ It seems strange that the vessel was made ready to sail and so was therefore presumably fully loaded (or as fully as possible) so long before the supercargo was ready; what was Whiteside doing in New York for so long? In holding up the vessel for such a long time for no apparent reason, Whiteside was surely negligent. As the vessel was in the river ready to sail he could not have been arranging more freight. It is possible that he could have been conducting legal business for Cunningham or one of the other venturers, but this long delay was clearly against the remit of any charter party. It was not good practise to hold up such heavily capitalised equipment as a sailing vessel. Whether he was working for the adventurers or on his own agenda during this time, this had serious repercussions on their [late] arrival in the West Indies, and far more so than Pearson's delay in Belfast.

It would seem that Whiteside was also to blame for the extraordinarily long stay in Nevis. Andrew Singleton reported that it was commonly known on board that Whiteside had an opportunity to sell all the cargo to one person residing on the island. ${ }^{66}$ John Dickenson, the ship's carpenter confirmed this. The fact that Whiteside had lost an opportunity to dispose of the cargo he thought 'delatory and negligent' especially as he had refused a reasonable 'markett[sic] Price for his Goods' ${ }^{67}$ Henry Thompson, the other foremastman, concurred. He said that Whiteside could have disposed of the cargo within six weeks of their arrival at Nevis, and at a better price than he later received. No doubt any buyers on the island realised he was getting desperate to dispose of his goods. ${ }^{68}$ To further stress Whiteside's culpability, Thompson added that he never knew of any fault in the master or the crew of the vessel, and that they had worked as fast as they could for the supercargo. John Dickenson agreed that Pearson and the crew were not at fault, and further noted that whilst the Providence was at Nevis [for over ten months] several other ships had been laden and sailed, including the Samuel, the Union from London and the Anvill from Bristol. Indeed, the latter had sailed from Nevis to Bristol and returned and re-laden all whilst the Providence was there. ${ }^{69}$ Even William Rollins, the one person who supported Whiteside on this issue by stating that Whiteside had been 'very diligent and industrious in his efforts', conceded that it would have been better for him to take 
the opportunity of the early sale. ${ }^{70}$ It is possible that Whiteside was simply trying to get the best price for Cunningham and the other merchants. The selling of goods, and the purchase of sugar, so far ahead of the harvest was bound to be slow. Perhaps he had wanted to go to Antigua as some of the adventurers may have had better networks there, but as mentioned above, he did not feel able to ensure full sales even there to Pearson. However, the fact that so many deponents mentioned that he could have sold the goods earlier and for a better price, does appear to put the blame firmly on Whiteside. He seems to have been working on his own agenda.

Whiteside, whether he was acting for the good of the ship, its crew and the adventurers or not, seems to have made some other poor decisions. During their stay at Nevis Whiteside ordered cable and a 'considerable quantity of cordage' to be brought on board by a sloop from St Thomas island, then belonging to the Dutch. Henry Thompson clearly thought these were stolen, or at the very least put on board illegally. He reported that when the 'Queen's officers were preparing to come on board' to search the vessel, the cable and cordage were thrown overboard to prevent seizure of the vessel. ${ }^{71}$ Andrew Singleton also reported the same event. ${ }^{72}$ Even if the vessel was in desperate need for these items, stolen or not, and that Whiteside was acting for the best of the crew; it surely would have been better to purchase them legally at Nevis, or from another vessel. However, the Providence seems to have been sailed home successfully without these items, suggesting that in this Whiteside was working for his own advantage.

A last possible hint at some fraud by Whiteside came from Henry Thompson. Thompson mentioned that he had seen Whiteside ordering or instructing Miles Rimmer the mate how to write the 'markes' of several hogsheads then on board. ${ }^{73}$ Subsequently, Rimmer assisted Whiteside in changing the marks accordingly. Unfortunately the source does not tell us more about this incident and so we cannot know why this was done.

\section{Discussion}

Pearson's failures, the delay of the Providence for a week in Belfast and the taking on of coals without certification, caused delays in the voyage which had financial 
repercussions for the adventurers. However, his actions point to a lack of competence and knowledge rather than fraudulent activity. The decision to discourage people from freighting in the vessel from Nevis appears strange, but he does seem to have been acting honestly. His actions, no doubt part of socially-embedded behaviours, were possibly part of a long-term business strategy, even if it caused even higher dead freight charges for the Liverpool adventurers. ${ }^{74}$ They were certainly not the actions of a (short-term) rational economic man. It is also worth noting that much of the evidence against Pearson comes from Bibby, who seems to have held a grudge against him - although his accusations were corroborated by other deponents. ${ }^{75}$ The fact that Pearson was a plaintiff in the original case with Cunningham also suggests that their relationship had not broken down as a result of his actions. Pearson's case therefore points to an involuted failure on part of the network, due to lack of knowledge and skills or competency.

In contrast, in holding up the vessel for such a long time in New York and Nevis Whiteside was surely negligent, and possibly fraudulent. Both delays were clearly against the remit of any charter party (if it existed). In not accepting an early offer for his cargo in Nevis, Whiteside was perhaps waiting for a better price, which he may have got nearer the harvest period. However, the Providence did not leave Nevis until well after the next harvest had finished, which was inexcusable. Taking on board (apparently) illegal cable and cordage also seems to have cost money, which may have been his own money as part of a private venture. Certainly the Providence seems to have sailed back to Liverpool safely without these items. Whiteside definitely caused the most delays, and instigated the high demurrage charges that became due by the adventurers. The fact that Whiteside was a defendant in the case brought by Cunningham suggests that he was not acting on his behalf, or according to instructions. He was also co-defendant and co-plaintiff with the majority of the other merchants involved in the venture. However, he may have been acting along with them in arguing that there was no charter party in order to divert blame from himself because of the high costs involved in dead freight and demurrage if it were judged that there was a valid charter party. Whiteside's behaviour does appear fraudulent or that he was at least acting on his own behalf, and therefore represents a contested part of the network. 
The decision about which island to go to in the Leeward Islands, which was clearly a matter of dispute, was supposed to have been agreed to in New York by both Pearson and Whiteside. $^{76}$ The orders to delay this decision until they (presumably) had better or later knowledge available in New York came from Cunningham. This delayed decision seems to have been normal in the peripatetic trade of this period; however, he should have given the decision to one or other of the men to avoid such arguments. Both Pearson and Whiteside contributed to the lengthy nature of the voyage. However, the voyage never left Liverpool at a good point in time for either a New York or a West India arrival. So we could place the blame on Cunningham as ship's husband and owner, because the original planning was not good either. Therefore, it was not just Pearson and Whiteside who were to blame for the problems related with this adventure.

It was not possible to establish whether Pearson or Whiteside worked with Cunningham or any of the other merchants before or after this case from the Port Books, because the captain is not always listed, and the supercargo not at all - unless importing on his own account. This means that without further evidence we cannot assess the long-term nature of Pearson and Whiteside's relationship with the rest of the Liverpool network, although some of the merchants imported on the same vessels previous to this voyage. Neither is it possible to say to what extent Cunningham's non-conformity and exclusion from the town council isolated him. He was certainly isolated in terms of the court case from the majority of the merchants, but whether this was religious politics or simply down to the others not wanting to pay dead freight and demurrage is unknowable from the available sources. At the same time, the arbiters, many of which were on the town council seemed to have found in his favour (perhaps because as merchants they would have liked a similar finding for themselves); but again, we cannot tell whether politics or economics was the driving force.

\section{Conclusion}

The case study of the Providence shows that relative failure of both types, involuted and contested, can be present in one network at the same time. The behaviour of Pearson and Whiteside had serious financial repercussions for the owner 
Cunningham, as well as the other merchant adventurers. However, the voyage was not well planned or timed from the start, for which failure we need to look to Cunningham. Nor did Cunningham or Pearson apparently make the existence of any charter party sufficiently clear to the others freighting on the vessel from Liverpool. However, this venture occurred early in Liverpool's Atlantic trade. Although some of the merchants had traded to the West Indies beforehand - and collectively Liverpool merchants had been trading to the West Indies since at least 1665, it appears that the networks on the Western side of the Atlantic were still developing and underdeveloped. This meant that clearer or more precise instructions could not be given to the captain and supercargo, leaving the requirement for this journey to be rather peripatetic. Moreover, this lack of networks meant that there were no actors in place to advise, govern and/or report on the behaviour of Pearson and Whiteside in the Americas. Although the institution of the Exchequer was available to resolve this issue, transaction costs would have been much lower had good governance networks been in place.

This does not necessarily mean that this network failed. This venture may have been only partly successful, but it did not deter Cunningham or the other merchants investing in similar voyages afterwards, so they must have considered it at least partly successful, if only in gaining new information and experience (developing competence) as part of a learning process. Furthermore, other merchants in the wider Liverpool trading community ventured into the West Indies in the decades that followed. Indeed, Liverpool became the leading Atlantic out port during the 1740s. Therefore, incompetency and fraud caused both Pearson and Whiteside to have 'bad ideas' within the structural hole(s) they were bridging, but this does not mean that the network failed; just that it was one which had both involuted and contested elements within it. The behaviour of Pearson and Whiteside should be seen as a 'best case scenario' within the context of a developing and as yet under-developed network. 


\section{Bibliography}

\section{$\underline{\text { Primary Sources }}$}

The National Archives

HM Court of Exchequer,

Interrogatories, E 134/1Geo1/Mich 37 April 1714.

Interrogatories, E134/1Geo1/East21, 18 April 1715.

Decree, Whereas John Cunningham \& Joseph Pearson ..., E 190/30, f. 18, 1716.

Port Books, Chester, Liverpool, Customer Overseas, E 190/1337/16 (1664-65);

E290/1377/22 (1709-10); E190/1387/7 (1714-15).

\section{Printed}

Mortimer, T., A New and Complete Dictionary of Trade and Commerce: Containing a Distinct Explanation of the General Principles of Commerce ... (London, 1766).

\section{$\underline{\text { Secondary Literature }}$}

Ascott, D. E. F. Lewis and M. Power, Liverpool, 1660-1750: People, Prosperity and Power (Liverpool: Liverpool University Press, 2006).

Baugh, D. A., 'Britain's Blue Water Policy, 1689-1815', International History Review, 10:1 (Feb 1988), pp. 33-58.

Bryson, W. H., The Equity Side of the Exchequer: Its Jurisdictions, Procedures and Records (Cambridge: Cambridge University Press, 1975).

Burt, R. S., 'Structural Holes and Good Ideas', American Journal of Sociology, 10:2 (2004), pp. 349-99.

Buskens, V., and A. van de Rijt, 'Dynamics of Networks if Everyone Strives for Structural Holes', American Journal of Sociology, 114:2 (Sep 2008), 371-407. 
Casson, M., 'Entrepreneurial Networks in International Business', Business and Economic History, 26:2 (Winter 1997), pp. 811-23.

Crouse, N. M., The French Struggle for the West Indies, 1665-1713 (New York: Columbia University Press, 1943).

Crumplin, T., 'Opaque Networks: Business and Community in the Isle of Man, 18401900’, Business History, 49:6 (2007), pp. 780-801.

Dunn, R. S., Sugar and Slaves: The Rise of the Planter Class in the English West Indies, 1624-1713 (Chapel Hill and London: University of North Carolina Press, 1972).

Forrestier, A., 'Risk, Kinship and Personal Relationships in Late Eighteenth-Century West Indian Trade: The Commercial Network of Tobin \& Pinney', Business History, 52:6 (2010), pp. 912-31.

Grabowski, R., 'Market Evolution and Economic Development: The Evolution of Impersonal Markets', American Journal of Economics and Sociology, 58:4 (Oct 1999), pp. 699-712.

Granovetter, M. S., 'The Strength of Weak Ties', American Journal of Sociology, 78:6 (May, 1973), 1360-80; R. S. Burt, Structural Holes: The Social Structure of Competition (Cambridge, MA.: and London: Harvard University Press, 1992).

Granovetter, M. S., 'Economic Action and Social Structure: The Problem of Embeddedness', American Journal of Sociology, 91:3 (Nov 1985), pp. 481-510.

Haggerty, S., 'Merely for Money'? Business Culture in the British Atlantic, 17501815 (Liverpool: Liverpool University Press, 2012). 
Hancock, D., 'The Trouble with Networks: Managing the Scots' Early-Modern Madeira Trade', Business History Review, 79, Special Edition on Networks in the Trade in Alcohol (Autumn 2005), pp. 67-91.

Hattendorf, J. B., England in the War of the Spanish Succession: A Study in the English View and Conduct of Grand Strategy, 1701-1713 (Abingdon: Taylor and Francis, 1987), chapter 12, 'English Conduct of the War During the Search for Peace, 1710-1713', pp. 231-72.

Koot, C. J., Empire at the Periphery: British Colonists, Anglo-Dutch Trade, and the Development of the British Atlantic, 1621-1713 (New York and London: New York University Press, 2011).

Lawler, E. J., and Y. Yoon, 'Commitment in Exchange Relations: Test of a Theory of Relational Cohesion', American Sociological Review, 61:1 (Feb 1996), pp. 89-108.

Lenman, B. P., 'Colonial Wars and Imperial Instability, 1688-1793', in P.J. Marshall (ed.), Oxford History of the British Empire, Vol. II, The Eighteenth Century, pp. 15168.

Lynn, J. A., The Wars of Louis XIV, 1667-1714 (Longman: London and New York, 1999).

Mancke, E., 'Chartered Enterprises and the Evolution of the British Atlantic World', in E. Mancke and C. Shammas (eds.), The Creation of the British Atlantic World (Baltimore and London: Johns Hopkins University Press, 2005), pp. 237-62.

Mathias, P., 'Risk, Credit and Kinship in early Modern Enterprise', in J. J. McCusker and K. Morgan (eds.), The Early-Modern Atlantic Economy (Cambridge: Cambridge University Press, 2000), pp. 15-35.

Matson, C., Merchants and Empire: Trading in Colonial New York (Baltimore and London: Johns Hopkins University Press, 1998). 
Podolny, J. M., and K. L. Page, 'Network Forms of Organization', Annual Review of Sociology, 24 (1998), pp. 57-76.

Poole, B., Liverpool's Trade in the Reign of Queen Anne (Unpublished MA Thesis, University of Liverpool, 1961), pp. 101-109.

Popp, A., 'Building the Market: John Shaw of Wolverhampton and Commercial Travelling in Early nineteenth-Century England', Business History, 49:3 (May 2007), pp. 321-47.

Power, M., 'Creating a Port: Liverpool 1695-1715', Transactions of the Historic Society of Lancashire and Cheshire, 149 (1999), pp. 51-71.

Prior A., and M. Kirby, 'The Society of Friends and the Family Firm, 1700-1830', Business History, 35:4 (1993), pp. 66-85.

Rose, M. B., 'The Family Firm in British Business, 1780-1914', in M. W. Kirby and M. B. Rose (eds.), Business Enterprise in Modern Britain from the Eighteenth to the Twentieth Century (London, 1994), pp. 61-87.

Schrank, A., and J. Whitford, 'The Anatomy of Network Failure', Sociological Theory, 29:3 (2011), pp. 151-77.

Sheridan, R. B., Sugar and Slavery: An Economic History of the British West Indies, 1623-1775 (Kingston, Jamaica: Canoe Press, 1974), pp. 218, 259-50.

Stammers, M. K., 'Ships and Port Management at Liverpool Before the Opening of the First Dock in 1715', Transactions of the Historic Society of Lancashire and Cheshire, 156 (2007), pp. 27-50.

Starkey, D. J., British Privateering Enterprise in the Eighteenth Century, Exeter Maritime Series No. 4 (Exeter: University of Exeter Press, 1990). 
Steckley, G. F., 'Freight Law in the Seventeenth-Century Admiralty Court', Journal of Legal History, 27:2 (2006), pp. 175-97.

Strong, N., and M. Waterson, 'Principals, Agents and Information', in R. Clark and T. McGuiness (eds.), The Economics of the Firm (Oxford: Basil Blackwell Ltd, 1987), pp. 18-41.

Thye,,S. R., E. J. Lawler and J. Yoon, 'The Emergence of Embedded Relations and Group Formation in Networks of Competition', Psychology Quarterly, 74:4 (Dec 2011), pp. 287-413.

Zacek, N. A., Settler Society in the English Leeward Islands, 1670-1776 (Cambridge: Cambridge University Press, 2010).

Zucker, L. G., 'Production of Trust: Institutional Sources of Economic Structure, 1840-1920', Research in Organizational Behaviour, 8 (1986), pp. 53-111.

\footnotetext{
${ }^{1}$ My great thanks to S. Talbott and D. E. Ascott for very helpful discussions on earlier versions of this paper, and especially to the latter for pointing me to references concerning John Cunningham.

${ }^{2}$ For a positivistic approach see: P. Mathias, 'Risk, Credit and Kinship in early Modern Enterprise', in J. J. McCusker and K. Morgan (eds.), The Early-Modern Atlantic Economy (Cambridge: Cambridge University Press, 2000), pp. 15-35; M. B. Rose, 'The Family Firm in British Business, 1780-1914', in M. W. Kirby and M. B. Rose (eds.), Business Enterprise in Modern Britain from the Eighteenth to the Twentieth Century (London, 1994), pp. 61-87; A. Prior and M. Kirby, 'The Society of Friends and the Family Firm, 1700-1830', Business History, 35:4 (1993), pp. 66-85.

On the inherent problems with networks see D. Hancock, 'The Trouble with Networks: Managing the Scots' Early-Modern Madeira Trade', Business History Review, 79, Special Edition on Networks in the Trade in Alcohol (Autumn 2005), pp. $67-91$.
} 
${ }^{3}$ See for example, A. Popp, 'Building the Market: John Shaw of Wolverhampton and Commercial Travelling in Early nineteenth-Century England', Business History, 49:3 (May 2007), pp. 321-47; T. Crumplin, 'Opaque Networks: Business and Community in the Isle of Man, 1840-1900', Business History, 49:6 (2007), pp. 780-801; A. Forrestier, 'Risk, Kinship and Personal Relationships in Late Eighteenth-Century West Indian Trade: The Commercial Network of Tobin \& Pinney', Business History, 52:6 (2010), pp. 912-31. For ascribed trust see L. G. Zucker, 'Production of Trust: Institutional Sources of Economic Structure, 1840-1920', Research in Organizational Behaviour, 8 (1986), pp. 53-111.

${ }^{4}$ M. S. Granovetter, 'The Strength of Weak Ties', American Journal of Sociology, 78:6 (May, 1973), 1360-80; R. S. Burt, Structural Holes: The Social Structure of Competition (Cambridge, MA.: and London: Harvard University Press, 1992), p. 19.

${ }^{5}$ R. S. Burt, 'Structural Holes and Good Ideas', American Journal of Sociology, 10:2 (2004), pp. 349-99, p. 349.

${ }^{6}$ Structural holes can only last for so long. Due to the fact that they offer high rewards, entrepreneurs can get into a 'network race' to fill them, at the end of which it is unlikely that anyone will be in a privileged position. V. Buskens and A. van de Rijt, 'Dynamics of Networks if Everyone Strives for Structural Holes', American Journal of Sociology, 114:2 (Sep 2008), 371-407, p. 375.

${ }^{7}$ Burt, 'Structural Holes' p. 354.

${ }^{8}$ On adverse selection and moral hazard see N. Strong and M. Waterson, 'Principals, Agents and Information', in R. Clark and T. McGuiness (eds.), The Economics of the Firm (Oxford: Basil Blackwell Ltd, 1987), pp. 18-41.

${ }^{9}$ A. Schrank and J. Whitford, 'The Anatomy of Network Failure', Sociological Theory, 29:3 (2011), pp. 151-77, p. 155.

${ }^{10}$ Under absolute failure they demarcate between the non-appearance of networks (network stillbirth) and the breakup of existing networks (network devolution). Schrank and Whitford, 'Anatomy of Network Failure', p.153, and passim.

${ }^{11}$ Schrank and Whitford, 'Anatomy of Network Failure', p. 161.

${ }^{12}$ R. Grabowski, 'Market Evolution and Economic Development: The Evolution of Impersonal Markets', American Journal of Economics and Sociology, 58:4 (Oct 1999), pp. 699-712, pp. 707-8. J. M. Podolny and K. L. Page also argue that networks should help synthesise information, confer legitimacy and status, and reduce 
information and transaction costs, 'Network Forms of Organization', Annual Review of Sociology, 24 (1998), pp. 57-76.

${ }^{13}$ Granovetter, 'The Strength of Weak Ties', p. 213. On wanting to believe information that suits us see Richard T. Stillson, Spreading the Word: A History of Information in the California Gold Rush (Lincoln and London: University of Nebraska Press, 2006).

${ }^{14}$ S. R. Thye, E. J. Lawler and J. Yoon, 'The Emergence of Embedded Relations and Group Formation in Networks of Competition', Psychology Quarterly, 74:4 (Dec 2011), pp. 287-413; E. J. Lawler, and Y. Yoon, 'Commitment in Exchange Relations: Test of a Theory of Relational Cohesion', American Sociological Review, 61:1 (Feb 1996), pp. 89-108; M. S. Granovetter, 'Economic Action and Social Structure: The Problem of Embeddedness', American Journal of Sociology, 91:3 (Nov 1985), pp. 481-510, p.498.

${ }^{15}$ Granovetter, 'Economic Action', p. 487.

${ }^{16}$ M. Casson, 'Entrepreneurial Networks in International Business', Business and Economic History, 26:2 (Winter 1997), pp. 811-23.

${ }^{17}$ Interrogatories taken on behalf of John Cunningham, Merchant and Joseph Pearson, Mariner, for HM Court of Exchequer by English Bill ..., April 1714, E 134/1Geo1/Mich 37; Interrogatories taken on behalf of ..., E134/1Geo1/East21, 18 April 1715; Decree, Whereas John Cunningham \& Joseph Pearson ..., E 190/30, f.18, 1716, The National Archives, Kew (hereafter TNA). The case appears to have gone on longer, but the Decree of 1716, which is not conclusionary, is the last evidence found at the time of submission.

${ }^{18}$ G.F. Steckley, 'Freight Law in the Seventeenth-Century Admiralty Court', Journal of Legal History, 27:2 (2006), pp. 175-97.

${ }^{19}$ W. H. Bryson, The Equity Side of the Exchequer: Its Jurisdictions, Procedures and Records (Cambridge: Cambridge University Press, 1975), introduction and pp. 10-11. ${ }^{20}$ C. J. Koot, Empire at the Periphery: British Colonists, Anglo-Dutch Trade, and the Development of the British Atlantic, 1621-1713 (New York and London: New York University Press, 2011).

${ }^{21}$ D. E. Ascott, F. Lewis and M. Power, Liverpool, 1660-1750: People, Prosperity and Power (Liverpool: Liverpool University Press, 2006), p. 34. 
${ }^{22}$ M. Power, 'Creating a Port: Liverpool 1695-1715', Transactions of the Historic Society of Lancashire and Cheshire, 149 (1999), pp. 51-71.

${ }^{23}$ Exchequer, Port Books, Chester, Liverpool, Customer Overseas (hereafter Port Books), E190/1337/16, ff. 13, 58, TNA.

${ }^{24}$ M. K. Stammers, 'Ships and Port Management at Liverpool Before the Opening of the First Dock in 1715', Transactions of the Historic Society of Lancashire and Cheshire, 156 (2007), pp. 27-50.

${ }^{25}$ C. Matson, Merchants and Empire: Trading in Colonial New York (Baltimore and London: Johns Hopkins University Press, 1998).

${ }^{26}$ N. A. Zacek, Settler Society in the English Leeward Islands, 1670-1776

(Cambridge: Cambridge University Press, 2010), p. 18.

${ }^{27}$ J. B. Hattendorf, England in the War of the Spanish Succession: A Study in the English View and Conduct of Grand Strategy, 1701-1713 (Abingdon: Taylor and Francis, 1987), chapter 12, 'English Conduct of the War During the Search for Peace, 1710-1713', pp. 231-72. There had been more conflict in the Caribbean at the turn of the century, though occasional raids continued until the end of the war. N. M. Crouse, The French Struggle for the West Indies, 1665-1713 (New York: Columbia University Press, 1943). Neither Jamaica nor Barbados were attacked, although the French mounted a successful raid on Nevis in 1706 which allegedly led to loss of circa one million pounds. B. P. Lenman, 'Colonial Wars and Imperial Instability, 1688-1793', in P.J. Marshall (ed.), Oxford History of the British Empire, Vol. II, The Eighteenth Century, pp. 151-68.

${ }^{28}$ J.A. Lynn, The Wars of Louis XIV, 1667-1714 (Longman: London and New York, 1999), p. 341. Privateering had perhaps been a bigger issue during the first decade of the eighteenth century for Liverpool traders. B. Poole, Liverpool's Trade in the Reign of Queen Anne (Unpublished MA Thesis, University of Liverpool, 1961), pp. 101109. See also D. J. Starkey, British Privateering Enterprise in the Eighteenth Century, Exeter Maritime Series No. 4 (Exeter: University of Exeter Press, 1990). The interest in the mixture of trade and colonies could be called part of a 'Blue-water policy'. D.

A. Baugh, 'Britain's Blue Water Policy, 1689-1815', International History Review, 10:1 (Feb 1988), pp. 33-58.

${ }^{29}$ The East India Company took control of the Asiento in 1713, but they never had a monopoly on the trade to the Spanish colonies, nor did the Royal African Company in 
the British Atlantic slave trade. R. B. Sheridan, Sugar and Slavery: An Economic History of the British West Indies, 1623-1775 (Kingston, Jamaica: Canoe Press, 1974), pp. 218, 259-50, 317. See also E. Mancke, 'Chartered Enterprises and the Evolution of the British Atlantic World', in E. Mancke and C. Shammas (eds.), The Creation of the British Atlantic World (Baltimore and London: Johns Hopkins University Press, 2005), pp. 237-62.

${ }^{30}$ Deposition of Henry Orme, 16 November 1714, Interrogatories, E134/1Geo1/Mich37. John Cunningham was involved in 128 various shipments with regard to all his trading career. Ascott et al, Liverpool, 1660-1750, p. 153. This did not include the slave trade however. http://www.slavevoyages.org/tast/database/search.faces, accessed 14 May 2015. ${ }^{31}$ Deposition of Richard Norris, 16 November 1714, Interrogatories, E134/1Geo1/Mich37; Ascott et al, Liverpool, p.154. Richard Gildart had exported to Antigua on the Elizabeth during 1709/10, and William Clayton had traded to and from Antigua, St Christopher, Nevis and Barbados in the same year, on the Tyger, Goodspeed, Content, Neptune and Cleaveland, Port Books 1709-10, E190/1377/11, passim. M. J. Power, "Councillors and Commerce in Liverpool, 1650-1750”, Urban History, 24;3 (1997), 301-323. There were no merchant guilds in Liverpool.

${ }^{32}$ Deposition of George Tarvin, 16 Nov 1714, Interrogatories, E134/1Geo1/Mich37; Deposition of Henry Bibby, 18 April 1715, Interrogatories, E134/1Geo1/East21. ${ }^{33}$ Deposition of Edward Tarleton, 16 November 1714, Interrogatories, E134/1Geo1/Mich 37.

${ }^{34}$ Decree, 1716, E 190/30, f. 18, p. 1.

${ }^{35}$ The vessel was supposed to stay ' 45 days running' whereas this stay was ninety-one days long, Decree, 1716, p. 1.

${ }^{36}$ Deposition of Henry Bibby, 18 April 1715, Interrogatories, E134/1Geo1/East21; the vessel was only supposed to stay at the Leeward Islands for 'sixty five days', Decree, 1716, p. 3.

${ }^{37}$ Charter parties are voluntary agreements wherein a number of traders contract for a vessel to make a certain journey in a certain time. Extra charges are shared for space not taken up (dead freight) and for delays on the voyage (demurrage). See T. 
Mortimer, A New and Complete Dictionary of Trade and Commerce: Containing a

Distinct Explanation of the General Principles of Commerce ... (London, 1766).

${ }^{38}$ Steckley, 'Freight Law'.

${ }^{39}$ Deposition of Thomas Oldfield, 18 April 1715, Interrogatories,

E134/1Geo1/East21, TNA.

${ }^{40}$ Deposition of Edward Tarleton, 16 November 1714, Interrogatories,

E134/1Geo1/Mich 37.

${ }^{41}$ Decree, 1716 , p. 4. Portage is getting a vessel or its cargo from one navigable place to another.

42 Deposition of Thomas Oldfield.

${ }^{43}$ For example, John Cunningham imported c. 200 Cwt of sugar on the Happy

Entrance, 13 September 1705. Robert Tuite had imported muscovado sugar on the same vessel, 26 September 1705, Port Books 1704-5, E190/1337/16, f. 13, TNA.

Cunningham also imported 40 Cwt of sugar during 1709-10, Port Books, E190/1377/11.

${ }^{44}$ These 'interrogatories' are all listed on the first page(s) of each of

E134/1Geo1/Mich37 and E134/1Geo1/East21.

${ }^{45}$ Deposition of Henry Bibby.

${ }^{46}$ Deposition of George Marsden, 18 April 1715, Interrogatories, E134/1Geo1/East21.

${ }^{47}$ Deposition of Henry Thompson, 15 April 1715, Interrogatories, E134/1Geo1/East21.

${ }^{48}$ Support from the Crew was very important in these freight cases. Steckley, 'Freight Law', p.181.

${ }^{49}$ Deposition of Henry Thompson.

${ }^{50}$ Deposition of Henry Bibby.

${ }^{51}$ Deposition of Henry Bibby.

52 Thompson was formerly sworn in 'on the Defendant's Part' but was this time sworn and Examined on the Complainant's part.

53 John Cunningham did import from Antigua in later years. See for example, the Susanna in January 1714, Port Books, 1714-15, E190/1387/7, f. 24, TNA. His brother-in-law, Samuel Danvers, was the firm's representative in Antigua at some point but as yet it has not been possible to discover which years. My thanks to D. E. 
Ascott for this information. If Danvers was in Antigua at this point it is strange that Cunningham did not direct the vessel there.

${ }^{54}$ Zacek, Settler Society, p. 19.

${ }^{55}$ Deposition of Andrew Singleton, 15 April 1715, Interrogatories, E134/1Geo1/East21.

${ }^{56}$ Anthony Booth traded with Antigua; Edward Leeth, Barbados; Robert Tuite, Antigua mainly, but also Jamaica and St Christopher; William Clayton, Antigua mostly, but also St. Christopher, Barbados and Nevis. Port Books, 1709-10, E190/1377/11.

${ }^{57}$ On the cultivation of sugar see R. S. Dunn, Sugar and Slaves: The Rise of the Planter Class in the English West Indies, 1624-1713 (Chapel Hill and London: University of North Carolina Press, 1972), chapter 6, 'Sugar', pp. 188-223.

${ }^{58}$ Deposition of Henry Bibby.

${ }^{59}$ Some of the blame regarding this can be apportioned to Cunningham, see the discussion below.

${ }^{60}$ Deposition of Henry Bibby.

${ }^{61}$ Deposition of Henry Bibby.

${ }^{62}$ Zacek, Settler Society, pp.41-42; Lenman, 'Colonial Wars', p. 155.

${ }^{63}$ Decree, 1716, pp .1-2.

${ }^{64}$ Deposition of Henry Thompson.

${ }^{65}$ Deposition of Andrew Singleton.

${ }^{66}$ Deposition of Andrew Singleton.

${ }^{67}$ Deposition of John Dickenson, 16 November 1714, Interrogatories, E134/1Geo1/Mich37.

${ }^{68}$ Deposition of Henry Thompson.

${ }^{69}$ Deposition of John Dickenson.

${ }^{70}$ Deposition of William Rollins, 16 November 1714, Interrogatories,

E134/1Geo1/Mich37. Even Andrew Singleton allowed that he had taken the long boat to St. Christophers to enquire into the market there. Deposition of Andrew Singleton.

${ }^{71}$ Deposition of Henry Thompson.

${ }^{72}$ Deposition of Andrew Singleton.

${ }^{73}$ Deposition of Henry Thompson. 
${ }^{74}$ See S. Haggerty, 'Merely for Money'? Business Culture in the British Atlantic, 1750-1815 (Liverpool: Liverpool University Press, 2012).

${ }^{75}$ Bibby claimed that Pearson had not allowed him to put sugars on the Providence at Nevis, but Henry Thompson stated that those refused were because Bibby had already reached his allowance as a sailor on board. Deposition of Henry Thompson.

${ }^{76}$ Decree, 1716, p. 1. 